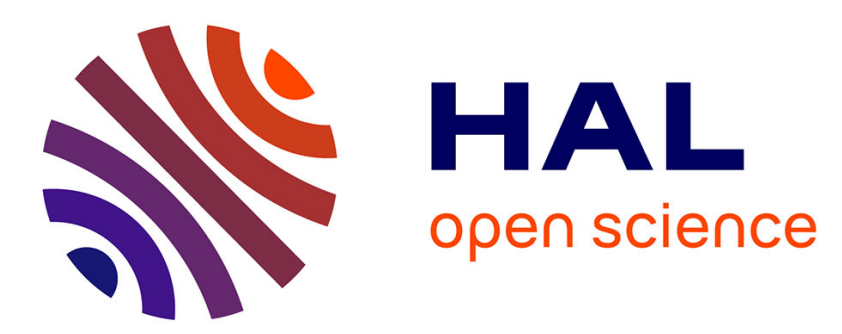

\title{
Developing critical analysis of explanations in physics teachers: Which direction to take?
}

\author{
Laurence Viennot
}

\section{To cite this version:}

Laurence Viennot. Developing critical analysis of explanations in physics teachers: Which direction to take?. Physics Education, 2019. hal-02320267

\section{HAL Id: hal-02320267 \\ https://hal.science/hal-02320267}

Submitted on 18 Oct 2019

HAL is a multi-disciplinary open access archive for the deposit and dissemination of scientific research documents, whether they are published or not. The documents may come from teaching and research institutions in France or abroad, or from public or private research centers.
L'archive ouverte pluridisciplinaire HAL, est destinée au dépôt et à la diffusion de documents scientifiques de niveau recherche, publiés ou non, émanant des établissements d'enseignement et de recherche français ou étrangers, des laboratoires publics ou privés. 
VIENNOT L. 2019. Developing critical analysis of explanations in physics teachers: Which direction to take?

Phys. Educ. Accepted Oct 15 ${ }^{\text {th }}, 2019$, PED-101942

\section{Developing critical analysis of explanations in physics teachers: Which direction to take?}

\section{Laurence Viennot}

\section{Introduction}

This paper is inspired by the widely accepted need to develop critical thinking in physics students and teachers. As Bailin and Siegel argued, 'critical thinking is often regarded as a fundamental aim and an overriding ideal of education' [1] (p. 188). Official reports about science education (e.g. [2]) align with this view and universally advocate for critical thinking as a priority objective in this field. This article discusses how to help teachers and students 'to contend with ambiguities, to make sound judgments about what to accept and what to question' [3] regarding explanations in science education. The phrase critical analysis will be used below to designate an observable intellectual activity of this type.

That said, the paper adopts a limited approach to critical analysis; in particular, 'controversial' or 'socio-scientific' issues are not addressed here, despite their crucial importance [4,5]. The target context is in principle less complex: texts that are commonly used in physics education or that explicate phenomena commonly taught in an academic framework and/or in popularised accounts. The issue of what to conclude from an experiment is an essential component of an education in critical analysis [6]. The complementary approach developed here is based on Norris and Phillips' assertion [7]: 'Science (...) could not exist as an oral tradition; texts are essential, not optional. They are a constitutive feature of science-just as empirical data collection is. An understanding of science therefore requires the ability to read texts' (p. 1502). On this view, the question is how we might promote this ability in teachers as well as students. Critiquing an explanation should be seen, first and always, as a means of more fully understanding a topic and identifying a direction for personal research. An individual or a group can be said to have mastered a topic when appropriate explanations can be produced and their conditions of validity analysed and when contestable arguments can be appropriately discussed and potentially rejected. Moreover, concerning teachers, an efficient critical analysis of explanations in physics can be seen as opening the door to well informed pedagogical decisions. Indeed, it is often the case that several explanations are available for a given physical phenomena, and it seems desirable to have explicit criteria to choose the most appropriate one for a given audience.

What can be done to reach these goals? In relation to ordinary topics of physics and explanations introduced during ordinary physics teaching, what direction should one take?

After recalling some results from previous related investigations (section 2), the main anticipated obstacles to the development of a critical attitude will be discussed (section 3). A tool to effectuate a multifaceted 'quality diagnosis' of explanations will then be described (section 4), followed by some 
examples of how to use it (section 5). The final section (6) will summarise the benefits and limitations of such a tool, and wider ranging suggestions will be advanced for fostering critical analysis in physics education.

\section{A few observations from empirical research}

To begin, it is useful to note that the texts to be criticised are not confined to controversial ideas such as 'the Earth is flat'; there are many flawed explanations in common teaching contexts too. Although it is hard to accept, there are many examples of 'teaching rituals' - that is, contestable explanations that are both very common and undiscussed. These include the idea that a hot air balloon can stay at a stable altitude with the same pressure everywhere around the envelope and inside [8], or the common explanation of the movement of electrons in a circuit exclusively in terms of the charge on the battery poles $[9,10]$. There are many other such examples, as for instance in [11].

The persistence of such rituals over decades [12] implies a certain tolerance on the part of teachers and textbook writers. In a series of investigations based on interviews with beginning teachers [13], it has been observed that such critical passivity may occur in persons with all the necessary knowledge to criticise a flawed explanation - a condition we characterised as expert anaesthesia (Table 1).

Table 1. Three types of critical response when discussing a questionable explanation in physics [13]

\begin{tabular}{lll}
\hline $\begin{array}{l}\text { Type of } \\
\text { critical } \\
\text { response }\end{array}$ & Description & $\begin{array}{l}\text { Observed } \\
\text { frequency in } \\
\text { beginning } \\
\text { teachers }\end{array}$ \\
\hline $\begin{array}{l}\text { Expert } \\
\text { anaesthesia }\end{array}$ & $\begin{array}{l}\text { Absence of criticism in someone with all the necessary } \\
\text { knowledge of a field to detect an inconsistency or serious } \\
\text { inadequacy in an explanation relating to that field }\end{array}$ & $\begin{array}{l}\text { Variable } \\
\text { frequency } \\
\text { according to } \\
\text { physical domain }\end{array}$ \\
\hline $\begin{array}{l}\text { Delayed } \\
\text { critique }\end{array}$ & $\begin{array}{l}\text { A subjective need to know more about a field before making } \\
\text { any criticism of an explanation within this domain, even if no } \\
\text { specialised knowledge is required }\end{array}$ & $\begin{array}{l}\text { Majority of the } \\
\text { population }\end{array}$ \\
\hline Early critique & $\begin{array}{l}\text { Expression of a relevant criticism [...] even if one knows very } \\
\text { little about the field in question }\end{array}$ & Rare \\
\hline
\end{tabular}

In another form of critical passivity, the individual avoids articulating any critique until they feel they have achieved a thorough understanding of the topic in question-even if no specialised knowledge is required to detect a flaw in the explanation. This was by far the most frequent issue; we named it delayed critique. Conversely, in early critique, someone may articulate a relevant critique without any deep knowledge of the domain. This (rare) case constitutes a highly desirable objective for science education, and especially for beginning teachers. Indeed, students and teachers are increasingly led to seek information about various topics in books or on the web because they don't know about these 
topics. Clearly, it would be counterproductive to wait for complete knowledge of a topic before articulating any critique of a related explanation.

\section{What are the main obstacles to the development of critical analysis?}

The anticipated obstacles to developing the capacity for critical analysis differ somewhat for each of the two cases of critical passivity reported above.

In cases of delayed critique, one very important obstacle mentioned by beginning teachers when interviewed [13] is the feeling of incompetence. This feeling may concern the content itself, as for this beginning teacher.

- in this... err... As I have no particular competence in this domain, I am obliged to trust what I am taught (...). I have no clear cut position because I am not competent-I think I am not competent enough.

More broadly, the issue may relate to one's ability to criticise a text:

-We both came out saying that we were unable to analyse the texts as you did; there are many things we hadn't seen.

- I'm seriously questioning my own abilities because I feel I'm not capable of doing this (critical analysis) on my own.

-Who am I to criticise what important people have written?

Existing habits are also an aggravating factor, as for instance in these excerpts concerning the angle of contact of a liquid on a solid in the presence of a gas [14].

- I accept this explanation because I always did so, but I never questioned whether it was legitimate to apply, err, forces on an immaterial line.

-It's not that it worries me (or not); it's that this was my only conception (forces acting on a point or on a line), and this disrupts those conceptions, actually.

Regarding 'expert anaesthesia', one likely obstacle to critique is that, when we know a topic, we don't really read the text for what it is. Instead, we probably look for confirmation of what we know, and we feel reassured when we get this confirmation. If something that we know is missing from the explanation, we may complete the text more or less unconsciously. Clearly, habits are also an aggravating factor; in such situations, the difficulty lies in getting some distance from what we knowrituals included — to analyse what a novice might actually find in this text.

Another obstacle that can hinder both adepts of delayed critique and individuals experiencing expert anaesthesia is a flawed explanation that yields the correct conclusion. A typical case is 'the isobaric hot air balloon'-the flawed hypothesis according to which the pressure is the same everywhere around the envelope as well as inside it. This contradicts the fundamental principle of fluid statics - that is, the role of pressure gradients in flotation. However, as using this hypothesis to calculate Archimedes' up-thrust produces an acceptable result regarding the hot air balloon's condition of equilibrium, critique becomes all the more difficult.

\section{Helping physics teachers to critically analyse explanatory texts}

Given the frequency of cases of absent or reluctant critique and the obstacles described by some beginning teachers (feelings of incompetence, the influence of habit) or inadvertent correction of the text and the accuracy of conclusions as a misleading factor, what can we do? To facilitate the 
activation of critical analysis in science teachers, it seems useful to intervene at several levels, one of which is the psycho-cognitive level. As noted above, when confronted with an explanation of an unfamiliar topic, some individuals may be inhibited by a sense of incompetence; others may exhibit excessive self-confidence, confusing the fact that the text is clear with a belief that they understand the topic. It seems likely that an awareness of these trends is useful and should be developed in each individual. This paper introduces a tool that may facilitate such awareness through precise intervention in critique.

A recent book [15] provides an example of what this perspective can achieve. The authors proposed a twofold grid of analysis; first, the main flaws affecting an explanatory text are listed with examples (Table 2). This list specifies reasons that would indisputably lead to the rejection of an explanation or introduce a strong element of doubt - for instance, the reader is invited to look for a possible internal contradiction, or to pinpoint a missing link in an argument that is presented as logical. A second list (Table 3) specifies factors (also with examples) that may prompt misleading interpretations, as for example in the case of a 'linear causal argument' characterised by causal chaining of simple events that involve only one variable at a time. More simply, inaccurate designations of the entities involved in an explanation, as well as certain shortcuts and images, can be very misleading, although the consequences of these risks are highly dependent on the target audience.

Table 2. Types of flaw that indisputably invalidate an explanation or introduce a strong element of doubt

\begin{tabular}{|c|c|}
\hline Type of flaw & Example \\
\hline Internal contradiction, & $\begin{array}{l}\text { Saying (in the same text) that the pressure below the meniscus in a } \\
\text { capillary tube partly filled with liquid is at once greater and smaller than } \\
\text { the pressure above the meniscus }\end{array}$ \\
\hline Direct contradiction of a law & Saying that Newton's third law holds only for equilibrium situations \\
\hline Indirect contradiction of a law & $\begin{array}{l}\text { Speaking of a cyclist who accelerates without any friction between him or } \\
\text { the cycle and the ground }\end{array}$ \\
\hline $\begin{array}{l}\text { Logical incompleteness } \\
\text { that is, explanations in which at } \\
\text { least one link that is necessary for a } \\
\text { satisfactory explanation is missing }\end{array}$ & $\begin{array}{l}\text { A tautology, which is equivalent to no explanation at all: 'The velocity of } \\
\text { light in air is smaller than in empty space because the index of the air is } \\
\text { larger than 1.' } \\
\text { Arguing that, in radiocarbon dating, the }\left({ }^{14} \mathrm{C} /{ }^{12} \mathrm{C}\right) \text { composition of the } \\
\text { atmosphere is stable over time despite the radioactive decay of }{ }^{14} \mathrm{C} \text { without } \\
\text { explaining why. }\end{array}$ \\
\hline Over-generalisation & 'Objects made of a material denser than water don't float on water.' \\
\hline Incompatibility with a thought experiment & $\begin{array}{l}\text { 'The range of a jet emerging from a pierced bottle on the surface } \\
\text { supporting the bottle increases with the depth of the hole' (What about a } \\
\text { hole at the level of the surface supporting the bottle?) }\end{array}$ \\
\hline
\end{tabular}


Table 3 Summary of the main risk factors for critical text analysis

\begin{tabular}{|c|c|}
\hline Risk factor & Example \\
\hline $\begin{array}{l}\text { Accuracy of the text's conclusion } \\
\text { (which may undermine judgment) }\end{array}$ & The 'isobaric hot air balloon' (see text) \\
\hline $\begin{array}{l}\text { Echo-explanation } \\
\text { (explanations echoing common ideas) }\end{array}$ & $\begin{array}{l}\text { 'Showing rays of light' - for instance, with ray-boxes-without } \\
\text { explaining that light cannot be seen from the side }\end{array}$ \\
\hline Non-standard designation of entities & $\begin{array}{l}\text { 'The acceleration of the period' } \\
\text { 'A pressure is a force distributed over a surface' }\end{array}$ \\
\hline All or nothing & Suggesting that a red pigment completely absorbs a green light \\
\hline 'Small' assimilated to 'zero' & $\begin{array}{l}\text { Speaking of a freefall champion jumping from a helium balloon at an } \\
\text { altitude where there is no atmosphere (see text below) }\end{array}$ \\
\hline $\begin{array}{l}\text { Taking into account fewer variables than } \\
\text { necessary } \\
\text { (i.e. "functional reduction") }\end{array}$ & $\begin{array}{l}\text { 'Fewer molecules implies less pressure' } \\
\text { (What about the temperature?) }\end{array}$ \\
\hline Taking account of only one location & $\begin{array}{l}\text { Arguing that in an inverted test tube partly filled with liquid over a } \\
\text { recipient filled with the same liquid, the only force acting on the liquid } \\
\text { column (other than its weight) is acting below it }\end{array}$ \\
\hline $\begin{array}{l}\text { Explicit story-like explanation } \\
\text { (a linear chain of cause-effect } \\
\text { relationships) }\end{array}$ & $\begin{array}{l}\text { Siphon: 'The water contained in the long branch of the siphon flows } \\
\text { out. A vacuum is created, and atmospheric pressure causes the water in } \\
\text { the container in which it is immersed to rise in the small branch' } \\
\text { (Yes, but atmospheric pressure also acts at the end of 'the long } \\
\text { branch'.) }\end{array}$ \\
\hline Suggested story-like explanation & $\begin{array}{l}\text { An image explaining the Hall effect, in which electrons first deviate } \\
\text { towards a side of the conductive sample (due to the magnetic force) } \\
\text { then end their route along the axis of the sample (due to the electric } \\
\text { force caused by an accumulation of electrons on the side) }\end{array}$ \\
\hline Image: Realism and symbolism & $\begin{array}{l}\text { Rays of light represented as bright lines that you can see with a } \\
\text { magnifying glass }\end{array}$ \\
\hline Image: Similarity of symbols & $\begin{array}{l}\text { Using the same type of arrows to represent: } \\
\text {-Forces and velocities } \\
\text {-Lines of sight and paths of light }\end{array}$ \\
\hline Image: Over-selectivity & Only one ray emerges from each of Young's slits \\
\hline Image: Structure and scales & Left/right disposition suggesting a story-like explanation \\
\hline Analogy/metaphor & $\begin{array}{l}\text { Liquefaction: 'Molecules can no longer resist intermolecular } \\
\text { attractions' } \\
\text { (but even in liquid, pressure remains positive, except at the free } \\
\text { surface) }\end{array}$ \\
\hline
\end{tabular}

On the basis of the elements summarised in Tables 2 and 3, it is possible to formulate a multifaceted diagnosis of physics explanations. However, it should be noted that such characterization can be usefully supplemented by other, possibly positive criteria, such as the simplicity or mnemonic 
value of the explanation in question, in order to highlight the strengths and weaknesses of such an explanation. In particular, the generalizability of an explanation to situations that are both different from and close to the one analysed is often an interesting aspect to consider.

It should also be noted that it may be far from obvious whether an explanation belongs to a given category. This is not a serious problem because the objective of this type of tool is not to rigidly apply a classification algorithm but to stimulate reflection. For instance, regarding the category "logical incompleteness", no analysis is entirely complete, there are always missing aspects. As Ogborn writes [16], "Explanations are like the tip of an iceberg, with a large amount of supporting knowledge lurking below the surface" (p. 65). In the context of a "quality diagnosis", it is useful to pinpoint the cases where an essential link is missing in an argumentative chain and, logically, something prevents us from reaching a valid conclusion. This requires judgment. It is also important to identify "the supporting knowledge lurking below the surface" of an explanation, in other terms its prerequisites.

\section{The relevance of quality diagnosis of explanations}

The three examples below illustrate how to implement this 'quality diagnosis' approach. The criteria used to construct these grids are only those that are the most relevant in each case. As indicated above, a teacher may decide to add other criteria.

\section{Improving an explanation}

Imagine reading the following passage, analysed in [15, p.7] about a high-altitude freefall parachute jump in a popular journal.

To achieve this, he (the hero) will be equipped with a pressurised suit similar to those used by astronauts but adapted to resist extremely low temperatures below 110 degrees Kelvin and equipped with a parachute. He will reach an altitude of 40,000 meters in about three hours, aboard a capsule that is also pressurised and attached to a helium balloon. The duration of the jump is about six minutes and twenty five seconds. In the absence of an atmosphere, Fournier will pass the speed of sound (1067 kilometers/hour) about thirty seconds after his departure in a vertical position.

If you wished to use it for teaching purposes, it would be useful to analyse it first, as in Table 4.

Table 4. Quality diagnosis of an explanation of a freefall parachute jump (see text)

\begin{tabular}{llll}
\hline $\begin{array}{l}\text { Conceptual } \\
\text { simplicity/complexity }\end{array}$ & $\begin{array}{l}\text { Mnemonic } \\
\text { value }\end{array}$ & $\begin{array}{l}\text { Accuracy of the 'Small' assimilated to Contradiction of a law } \\
\text { conclusion } \\
\text { 'zero': }\end{array}$ \\
\hline $\begin{array}{l}\text { Easy to understand, } \\
\text { at first sight }\end{array}$ & $\begin{array}{l}\text { Easy to } \\
\text { remember }\end{array}$ & $\begin{array}{l}\text { Given the very low A very low pressure is A balloon cannot remain } \\
\text { pressure, the beginning of assimilated to zero in a stationary position at } \\
\text { the fall can be assimilated pressure, although it is altitude in the absence of } \\
\text { to a free fall. This may sufficient to provide the air. } \\
\end{array}$ \\
& $\begin{array}{ll}\text { seem to legitimise the required Archimedes' } \\
\text { statement that there is no up-thrust (via the } \\
\text { atmosphere at that pressure gradient). } \\
\text { altitude. }\end{array}$
\end{tabular}


Based on this analysis, it seems clear how the explanation can be improved without much loss to simplicity and clarity. To that end, one might refer to the very low atmospheric pressure at an altitude of $40 \mathrm{~km}$ (about $6.10^{-3} \mathrm{p}_{0}$ where $\mathrm{p}_{0}$ is the atmospheric pressure at sea level). We could add that the friction of the corresponding air on the parachutist is negligible compared to its weight, but that this non-zero value is essential to ensure (via Archimedes' up-thrust) the balance of the helium balloon at this altitude.

Table 5. Even in a popular article, an explanation can be improved at moderate cost in terms of simplicity

An explanation about a free fall record ... ...which might be improved on the basis of Table 4

"To achieve this, he (the hero) will be equipped with a pressurised suit similar to those used by astronauts but adapted to resist extremely low temperatures below 110 degrees Kelvin and equipped with a parachute. He will reach an altitude of 40,000 meters in about three hours, aboard a capsule that is also pressurised and attached to a helium balloon.

The duration of the jump is about six minutes and twenty five seconds. In the absence of an atmosphere*, Fournier will pass the speed of sound (1067 kilometers/hour) about thirty seconds after his departure in a vertical position. "
To achieve this, he (the hero) will be equipped with a pressurised suit similar to those used by astronauts but adapted to resist extremely low temperatures below 110 degrees Kelvin and equipped with a parachute. He will reach an altitude of 40,000 meters in about three hours, aboard a capsule that is also pressurised and attached to a helium balloon. At this altitude, the atmosphere is very tenuous (about $6.10^{-3} \mathrm{p}_{0}{ }^{* *}$ ) but sufficient for the balloon to hold in the air, (given the very large volume of the balloon, , Archimedes up-thrust ensures its flotation).

The duration of the jump is about six minutes and twenty five seconds. In the very tenuous atmosphere at the beginning of the free fall, the air friction is negligible compared to the weight of the champion. Fournier will pass the speed of sound (1067 kilometers/hour) about thirty seconds after his departure in a vertical position. .

* Bold: parts of the text which have been cancelled (in the original explanation) or added (in the modified explanation).

$* * \mathrm{p}_{0}$ is the value of atmospheric pressure at sea level.

The explanation remains relatively simple (Table 5), and the contradiction of Newton's second law has disappeared. It can be concluded that the revised explanation is more appropriate for a teenage or adult reader.

\section{Choosing between two explanations}

Flotation is a very popular topic in the early stages of science education, in particular to practice what is often called an Inquiry Based Science Teaching. By plunging blocks of materials of various densities in water, it is easy to "show" that "only objects less dense than water can float." Table 6 recapitulates various aspects of this statement, the important fact in this regard being that steel boats can float. 
Table 6. Quality diagnosis of the statement 'Only objects less dense than water can float in water'

\begin{tabular}{|c|c|c|c|c|c|c|}
\hline $\begin{array}{l}\text { Conceptual } \\
\text { simplicity/complexity }\end{array}$ & $\begin{array}{l}\text { Mnemonic } \\
\text { value }\end{array}$ & $\begin{array}{l}\text { Accuracy } \\
\text { of the } \\
\text { conclusion }\end{array}$ & $\begin{array}{l}\text { Logical } \\
\text { incompleteness }\end{array}$ & $\begin{array}{l}\text { Functional } \\
\text { reduction }\end{array}$ & $\begin{array}{l}\text { Contradiction } \\
\text { of a law }\end{array}$ & Generalisability \\
\hline $\begin{array}{l}\text { Easy to understand, } \\
\text { at first sight } \\
\text { BUT } \\
\text { density is an } \\
\text { intensive variable, } \\
\text { which may constitute } \\
\text { a difficulty }\end{array}$ & $\begin{array}{l}\text { Easy to } \\
\text { remember }\end{array}$ & $\begin{array}{l}\text { This } \\
\text { statement } \\
\text { is } \\
\text { compatible } \\
\text { with many } \\
\text { everyday } \\
\text { facts, } \\
\text { which may } \\
\text { undermine } \\
\text { judgment. } \\
\text { BUT } \\
\text { It } \\
\text { contradicts } \\
\text { the fact } \\
\text { that steel } \\
\text { boats can } \\
\text { float. }\end{array}$ & $\begin{array}{l}\text { No logical } \\
\text { arguments are } \\
\text { used }\end{array}$ & $\begin{array}{l}\text { Only one } \\
\text { variable is } \\
\text { taken into } \\
\text { account - } \\
\text { density-, } \\
\text { although } \\
\text { the shape } \\
\text { of the } \\
\text { object and } \\
\text { the way it } \\
\text { is put into } \\
\text { the water } \\
\text { also } \\
\text { matter. }\end{array}$ & $\begin{array}{l}\text { Yes, indirect } \\
\text { contradiction } \\
\text { of the law of } \\
\text { fluid statics } \\
\Delta p=-\rho g \Delta z \\
\text { (usual } \\
\text { notations) }\end{array}$ & $\begin{array}{l}\text { The extension } \\
\text { of this } \\
\text { explanation to } \\
\text { other fluids is } \\
\text { not obvious, } \\
\text { because the } \\
\text { density of the } \\
\text { object must be } \\
\text { referred to that } \\
\text { of the fluid } \\
\text { considered. }\end{array}$ \\
\hline
\end{tabular}

It should also be noted that the generalizability of this explanation to a different liquid requires comparing the density of the object with that of a liquid other than water.

Another approach to buoyancy proposed by Ogborn [17] can be characterised as the 'hole -in-water' explanation. It is based on the following argument.

Archimedes' up-thrust on an immersed body is the opposite of the push that must be applied to a thin empty and rigid envelope to make the same hole in the fluid (Fig. 1a and b). Placing a volume of the same fluid equal to the 'displaced volume' in this hole maintains the envelope at the same place without pushing it downwards or upwards (Fig 1c) (a thought experiment will suffice). It follows that Archimedes' up-thrust is the opposite of the weight of fluid now in the hole ('the displaced volume'). Instead of placing a volume of fluid equal to the "displaced volume" in the hole, it is possible to place a smaller volume of steel (Fig. 1d) while maintaining the envelope in the same place, which explains why steel boats can float.

Therefore, to predict whether an object can float, it is necessary to:

-determine the maximum volume of the hole that this object can make in the water;

-estimate the weight of the water that can be put in this hole (displaced fluid);

-compare it to the weight of the object to decide whether or not it can float. 


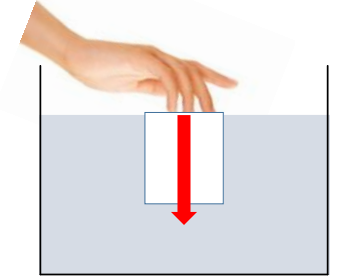

a

You have to push down to push the cup into the water

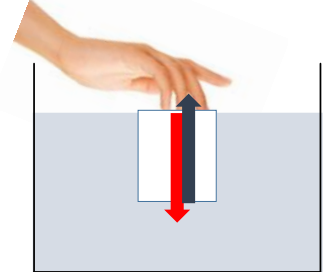

b

This is because another force acts in the opposite direction: Archimedes' thrust

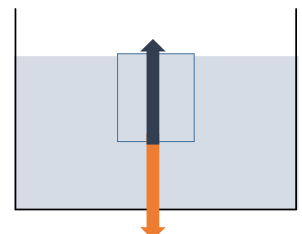

$\mathrm{c}$

There is no need to push anymore if we fill the cup with water to the level of the free surface.

So Archimedes' upthrust is opposed to the weight of the "displaced" water.

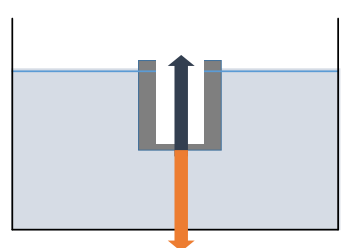

d

If the water cup has a steel shell, it's weight can also balance Archimedes' upthrust.

Fig. 1. The mains steps of the explanation proposed by Ogborn [17], here called "flotation-hole-in-thewater".

Table 7 summarises a quality diagnosis of this explanation.

Table 7. Quality diagnosis of the 'hole-in- the-water' explanation of flotation (see text)

\begin{tabular}{|c|c|c|c|c|c|c|}
\hline $\begin{array}{l}\text { Conceptual } \\
\text { simplicity/complexity }\end{array}$ & $\begin{array}{l}\text { Mnemonic } \\
\text { value }\end{array}$ & $\begin{array}{l}\text { Accuracy } \\
\text { of the } \\
\text { conclusion }\end{array}$ & $\begin{array}{l}\text { Logical } \\
\text { incompleteness }\end{array}$ & $\begin{array}{l}\text { Functional } \\
\text { reduction }\end{array}$ & $\begin{array}{l}\text { Contradiction } \\
\text { of a law }\end{array}$ & Generalisability \\
\hline $\begin{array}{l}\text { Easy to understand: } \\
\text { You can feel } \\
\text { Archimedes' up-thrust } \\
\text { with your hand (Fig. } \\
\text { 1a) } \\
\text { The variables in play } \\
\text { are extensive, which } \\
\text { may be easier to grasp. }\end{array}$ & $\begin{array}{l}\text { Easy to } \\
\text { remember }\end{array}$ & Yes & $\begin{array}{l}\text { You have to } \\
\text { admit that the } \\
\text { action of the } \\
\text { liquid on the } \\
\text { 'thin envelope' } \\
\text { does not depend } \\
\text { on what is } \\
\text { inside this } \\
\text { envelope. }\end{array}$ & $\begin{array}{l}\text { No: The two } \\
\text { relevant } \\
\text { variables } \\
\text { (weight of } \\
\text { the } \\
\text { "displaced } \\
\text { volume, } \\
\text { weight of the } \\
\text { object) are } \\
\text { taken into } \\
\text { account. }\end{array}$ & No & $\begin{array}{l}\text { It is easy to } \\
\text { extend this } \\
\text { explanation to } \\
\text { the case of other } \\
\text { fluids }\end{array}$ \\
\hline
\end{tabular}

Based on the two quality diagnoses in Tables 6 and 7, a teacher explaining flotation to a given audience can make an informed choice between the simplicity of the familiar slogan 'Only objects less dense than water can float in water' (which does not hold for steel boats) and the accuracy of the 'holein-the-water' explanation. Note that this second explanation can be associated with a physical experience, as you can 'feel' Archimedes' up-thrust when pushing an empty plastic cup into water. When comparing the two explanations, it is also worth noting that one involves an intensive variable (density), which may create a difficulty, especially for very young children. In contrast, the 'hole in the 
water' argument refers to extensive variables (weight of the immersed body and weight of the displaced volume), which may be easier to grasp.

It seems reasonable to conclude that these quality diagnoses support the 'hole-in-water' explanation, in line with Ogborn's arguments [16]. However, this is a matter of judgment, and a teacher might opt for the other explanation of flotation for a given audience. A quality diagnosis makes explicit the advantages and disadvantages of such a choice, in turn indicating warnings and complements that might usefully be added.

\section{Recapitulation and final remarks}

The above reflections are inspired by the general injunction to develop critical thinking among students and science teachers. Leaving aside crucial elements like socio-scientific issues or how to respond to fake news, the focus here is on helping physics teachers to critically analyse the explanatory texts about currently taught topics as used in ordinary teaching contexts. Limited as it is, this approach seems to respond to a real need, given the lack of relevant guidance.

Previous research [13] suggests that two opposing subjective states may hinder critical analysis in teachers: a paralyzing sense of incompetence when they feel ill-informed about a given subject, or overestimation of a text's explanatory value when they have a very good command of the subject. Two other important factors (in this case, common to all of us) influence critical passivity: teaching habits and the accuracy of conclusions drawn from an explanation. The potential influence of these psychocognitive effects makes education in critical analysis a more complex undertaking. The quality diagnosis approach to explanatory texts is proposed as a possible contribution to the education of science teachers in critical analysis of explanations, or simply as an aid to their current practice.

In fact, investigating how the use of a given explanation for teaching purposes can undermine understanding is not a new idea. The distance between explanations used in teaching and consensual expert accounts of the taught domain is known as didactic transposition [18]. In previous investigations [13], it has been observed that analysing this so-called distance proves very difficult for most teachers - a situation exacerbated by some experts' tolerance for certain flawed explanations.

As described here, the proposed tool guides analysis of the advantages and disadvantages of alternative explanations of physical phenomena. The approach is analytical - that is, it applies various criteria to assess the quality of an explanation by means of a multifaceted 'quality diagnosis'. Based on previous research [13], a twofold grid details possible flaws that would lead to the rejection of a given explanation or raise strong doubts about it, along with risk factors that may lead to misunderstanding or critical passivity in relation to an explanatory text. The grid can be completed, in particular by listing the positive aspects of each explanation, such as conceptual simplicity, generalizability, mnemonic value or other criteria. More generally, beyond the detail of this tool, the paper emphasises the principle of analytical diagnosis of quality, which can be adapted to the individual teacher's priorities by construction of their own grid. 
It is worth noting that it may be far from obvious whether an explanation belongs to a given category, and this requires judgment. The goal of this type of tool is not to rigidly apply an algorithm but to stimulate reflection, helping teachers to construct a kind of 'dashboard' to assist their teaching decisions. The three very simple examples illustrate how a teacher can use quality diagnosis to improve an explanation or to choose between two competing explanations.

More broadly, a grid of this type encourages the exploration of the 'pros and cons' of an explanation, - it highlights the fact that a given explanation is part but not all of the explanatory work and often constitutes a compromise between these pros and cons. This view is broader in scope than the idea that models are of limited value, because an explanation is more than a model. Like a model, an explanation is based on a selection of relevant aspects of the situation and on hypotheses; beyond that, however, an explanation consists of arguments that are logically organised. For instance, explaining radio-carbon dating without explaining why the atmosphere's $\left[{ }^{14} \mathrm{C} /{ }^{12} \mathrm{C}\right]$ composition is stable over time is not a problem of inappropriate modelling but of incomplete argumentation [19].

In conclusion, it seems fruitful to promote the idea of concept and critique as the two 'legs' of progress in understanding physics; critique facilitates better understanding, and understanding facilitates critique. In this regard, the requisite actions are not immediately obvious and must be negotiated by teachers or educators, taking due account of audience, context and constraints. As in [15], these efforts must be supported by dedicated activities and practical tools. It therefore seems fruitful to integrate critical analysis in education at all levels, independent of any immediate requirement to solve a problem. For instance, inviting comparative critical analysis of more or less complete and/or satisfying texts would stimulate future teachers' personal search for understanding. To this end, they should be encouraged to reflect on the most immediate objections to a text (e.g. internal or external inconsistency, logical incompleteness) and on the risk factors that engender critical passivity (e.g. expert anaesthesia, undue focus on the accuracy of the conclusion). It is worth noting that the benefits of this type of intellectual activity are not confined to highly contestable texts; any solved exercise can be used to engage student teachers in quality diagnosis and perhaps testing of the conclusion's generality - for instance, by modifying one hypothesis to see what should be changed (see examples in [18, Chap. 5]).

Existing evidence [13] indicates that it is not unrealistic to pursue gradual psycho-cognitive evolution in the targeted populations, whether to reduce the prevalence of expert anaesthesia or to convince non-experts that they are entitled to expect explanatory texts to be comprehensible, and to express their frustration when an explanation is defective, even if they know very little about the topic in question. Focusing students and teachers on their responsibility to actively accept or reject received explanations would also help to enhance their self-confidence. It is reasonable to conclude that science education can be enhanced by ensuring a better balance between concept and critique as key components of intellectual activity. 


\section{References}

[1] Bailin S and Siegel H 2003 Critical thinking, in The Blackwell Guide to the Philosophy of Education, edited by N Blake, P Smeyers, R. Smith and P. Standish (Blackwell, Oxford, UK) 181-183

[2] Redish E F and Hammer D 2009 Reinventing college physics for biologists: Explicating an epistemological curriculum Am. J. Phys. 77629

[3] European Commission 2015 Science education for responsible citizenship Report EUR 26893 (EN chair H. Hazelkorn, Brussels

[4] Erduran S and Jimenez-Aleixandre M. P. (Eds) 2007 Argumentation in Science Education Perspectives from Classroom-Based Research, Springer: Dordrecht

[5] Paul R.W. and Binker A. J. A. 1990 Strategies: Thirty-five dimensions of critical thinking, in Critical Thinking: What Every Person Needs to Survive in a Rapidly Changing World edited by A. J. A. Binker Sonoma State University Center for Critical Thinking and Moral Critique, Rohnert Park, CA, 305-349

[6] Etkina E and Planinšič G. Defining and developing “critical thinking” through devising and testing multiple explanations of the same phenomenon 2015 Phys. Teach. 53, 432

[7] Norris S and Phillips L 2003 How literacy in its fundamental sense is central to scientific literacy, Sci. Educ. 87, 224

[8] Viennot L 2006 Teaching rituals, and students' intellectual satisfaction, Phys. Educ. 41, 400

[9] Härtel H. 1985 The electric circuit as a system In R. Duit, W. Jung \& C. von Rhöneck (Eds.) Aspects of understanding electricity 343-352 Keil: Schmidt \& Klaunig

[10] Chabay R., \& Sherwood B. 2006 Restructuring the introductory electricity and magnetism course American Journal of Physics 74(4), 329-336

[11] Slisko J. 2006 Errores en los libros de texto de física: ¿cuáles son y por qué persisten tanto tiempo? Sinectica 27 13-23

[12] Viennot L 2016. The persistence of Teaching Rituals Physics Education 51(3), 030104

[13] Viennot L and Décamp N 2018 Activation of a critical attitude in prospective teachers: from research investigations to guidelines for teacher education Phys. Rev. Phys. Educ. Res. 14, 010133 https://doi.org/10.1103/PhysRevPhysEducRes.14.010133

[14] Viennot L and Décamp N 2018 The transition towards critique: discussing capillary ascension with beginning teachers Eur. J. Phys. 39045704 https://doi.org/10.1088/1361-6404/aab33f

[15] Viennot L. and Décamp N. 2018 L'apprentissage de la critique Développer l'analyse critique en physique Les Ulis: EDP Sciences-UGA (Grenoble) (English version in press : Springer)

[16] Ogborn J, Kress G, Martins I. and McGillicuddy K. 1996 Explaining Science in the Classroom (Open University Press, Buckingham).

[17] Ogborn J 2012 Archimedes' boat: making holes in water Phys. Educ. 47134

[18] Chevallard Y 1991 La transposition didactique. Grenoble: La pensée sauvage

[19] Décamp N and Viennot L 2015 Co-development of conceptual understanding, and critical attitude: Analysing texts on radiocarbon dating, Int. J. Sci. Educ. 37, 2038 